\title{
Evaluation in the process of professionalisation of social work
}

\begin{abstract}
There has been a long-standing discussion in Poland about the efficient and effective functioning of the social welfare and integration system. Transformations these systems have been undergoing for years, including reform attempts demonstrate that the issue of social work professionalisation is actually of little interest to anybody. If performed in a professional manner, methodical social work is a very important tool which may significantly contribute to increasing the efficiency and effectiveness of social interventions, thereby improving the quality of the public sphere in this segment. In this context, an important role is played by evaluation, understood as analysing the value of a specific action - with reference to social projects and programmes. Of particular importance here is the latest generation evaluation, which makes use of action research, thereby increasing the chances to raise the level of social participation and simultaneously reduce the problem of social exclusion. On the other hand, it is necessary to note the crucial role that evaluation may play in reinforcing and sustaining the professional identity of social
\end{abstract}

1 Correspondence: Institute of Sociology, University of Silesia, ul. Bankowa 11, 40-007 Katowice, author's email address: krystyna.faliszek@us.edu.pl 
workers, especially in the face of the constant changes and reforms of the social welfare system.

Key words: evaluation, social work, professionalisation, public sphere

\section{Introduction}

Since 2004, the year of Poland's accession to the European Union, i.e. to the broadly conceived system of social welfare and integration, there has been a massive inflow of financial support under the European Social Fund. In the consecutive EU budget expenditures (2000-2006; 2007-2013; 2014-2020), this system has received unprecedentedly high financial support under different EU programmes, today amounting to billions of Polish zlotys. This has paved the way for a qualitative change in Polish social welfare (security), through the development of social work in order to make social welfare institutions and centres active players in social policy-making, capable of using all the available instruments of social activation and integration. Moreover, it has provided social workers with an opportunity to upgrade and enhance their qualifications, which become invaluable not only in developing their own base of professional skills and knowledge, but also in the face of the global requirement for continuous learning. The social welfare and integration institutions themselves (at the level of municipalities [gmina], counties [powiat] and regions [województwo]) have also been given opportunities to develop and increase their potential with a view to the future when the generous EU financing will be limited or even stopped. This could also help them to more effectively change their negative, stigmatising image of an institution whose "... basic surface of functioning, instead of supporting social integration and counteracting exclusion, is the above-mentioned benefit granting" (Szyszka, 2013, p. 10). This has finally opened up a chance to significantly strengthen the non-governmental sector, which could become - to a greater extent than today - an important and authentic partner to the public sector. Thanks to the pressure from the European Union to evaluate the activities carried out using EU funds, there is increasing awareness that measurement and assessment of public interventions in social welfare is not only possible but necessary, with regard to both the so-called EU projects and all activities aimed at social change in any scale whatsoever.

There is no doubt that the EU funds have contributed to the changing image of Poland in its various dimensions, but the research conducted in the area of social policy and social welfare, as well as other areas (Faliszek, 2013; Faliszek et al., 2013; Górniak, 2005) shows that the effects of these changes are equivocal. Most doubts stem from the fact that, as can be clearly seen today, the EU funds could have been utilised much more effectively in a number of cases. Notwithstanding the numerous successes and spectacularly positive changes the funds have helped achieve, many opportunities to implement permanent transformations and create conditions for sustainable development, 
including the development of social work within the public social welfare system, have been squandered (Faliszek \& Leśniak-Berek, 2010). Another fact is that, in a number of cases, we cannot confidently say how much more we have really achieved with the aid of the EU funds than we would have without them. The discourse on social policy problems has long been accompanied by doubts of whether the financial support from the EU will help permanently change and improve the social security system in Poland or it is not rather the case, that the effects achieved are merely temporary and will disappear (or at least substantially decrease) once the EU funding is over. Theoretically, these doubts should be addressed by the evaluation surveys results, but the evaluation practice in the Polish "public" reality still leaves much to be desired.

\section{Evaluation in contemporary social work}

The contemporary model of social work is putting ever higher and more diversified professional demands on social workers. The prerequisite is to increase their independence and flexibility of action. Professional competence is indispensable for achieving the fundamental social work goal, in the form of assistance to individuals, families and communities in overcoming their life difficulties and recovering their ability to independently cope with them. The more client problems social workers will be able to understand and explain, and then choose appropriate solutions and operating procedures, the greater the opportunities for and effectiveness of their interventions will be. This means, in particular, the necessity to provide social workers with increasingly extensive knowledge to see further and deeper, and hence to perceive and define client issues in a broad context of their determinants and in multiple aspects, as well as recognise/find and make use of (client and environmental) resources available in the intervention process. This also means equipping social workers with the ability to react in a flexible manner and choose appropriate working methods in each individual case, conduct ongoing analyses of the relations between the numerous factors involved in a given situation, as well as properly define the their own and their clients' social roles. Finally, this means the ability to measure and assess the effects of their own work, which is to say to evaluate the actions they pursue and the subsequent results. For this reason, the links between evaluation and social welfare work are of particular relevance as their objectives are, to a large extent, convergent. If one may say that the aim of evaluation is:

...to improve the social functioning of the broadly conceived human systems, and hence the possibility of demonstrating the dynamics of the ongoing changes and enhancing the methods and strategies for providing individuals with the best possible living conditions (Ornacka, 2003, p. 129),

then it fully corresponds to the inherent purpose of social work.

It seems that evaluation in today's institutions of social welfare and integration is most commonly understood simply as a kind of assessment of a programme, project or 
activity. However, evaluation should not be identified with assessment, at least for a few reasons. Boiling evaluation down to pure assessment, however it might be understood, would in fact mean reducing it to merely one function, i.e. the control function. As noted by Leszek Korporowicz (2005, p. 4),

...this engenders widespread reluctance from those evaluated, and numerous defensive, apparent or simply ritual activities. Countries with developed systems of democratisation but also professionalisation of public life have been moving away from evaluation as a technocratic instrument of supervision and inspection hidden in research procedures since as early as the 1960s. Evaluation itself is moving away even from explicit forms of assessment in favour of analytical forms of counselling and methods for arousing reflexivity in those involved in the process, taking care of the possibilities for supporting actions.

Evaluation goes far beyond assessment, because its fundamental value is utility (usefulness), i.e. the possibility of practical application of the results, conclusions and findings obtained. It serves to modify, improve and enhance the measures taken so that they could produce optimum effects with regard to the diagnosed needs and possibilities, and best contribute to achieving the objectives pursued. Evaluation should assist project or programme implementers so that their actions would make it easier to achieve the objectives with more efficacy and effectiveness, and in a longer-term perspective. It should also serve the beneficiaries of those projects or activities, so that the results are adequate to their needs and obtained with due respect for their rights. Besides assessment, the concept of evaluation also includes elements of description and diagnosis, the indication of the programme's strengths and weaknesses, and — lastly — the requests and recommendations concerning recommended changes. The controlling and supervisory aspect of evaluation was the most prominent in its (now gradually abandoned) technocratic perspective, focused primarily on assessment and control, and - besides that - on description and legitimisation of the measures taken, as well as on criticism and disciplining (in the slightly later managerial perspective). Today, the preferred approach to evaluation is the one oriented towards development (the so-called Fourth Generation Evaluation) (Nowalska-Kapuścik, 2013). Its assumption is that evaluation should primarily be focused on change, understanding and support for all the stakeholders involved, as well as on the learning process and self-reflection. The evaluation process provides an excellent basis for strengthening communication and exchanging information, as well as for discussion and agreement between all the parties involved in a given activity, including evaluators, implementers and addressees of the programme/project. In such a perspective, well-conducted evaluation improves the quality and efficacy of public interventions, and the related learning process helps to increase the effectiveness of all stakeholders, including social workers themselves.

The importance of evaluation for the functioning of the public sphere is determined by the functions it can or should fulfil. The state-of-the-art presents various typologies of such functions. However, from the perspective of the social welfare system, the most interesting and useful seems to be the one proposed by David Nevo (1997). He identifies four most important functions of evaluation, including: 
- the formative function;

- the summative function;

- the psychological function;

- the administrative function.

Based on the analysis of the functions of evaluation proposed by various authors, one can indicate other important functions that may be fulfilled by evaluation studies with regard to public interventions and that seem to be of particular importance for the functioning of social welfare, namely:

— supporting the learning processes;

- explaining the factors and processes that influence the activities performed and determine their success or failure (also in the case of adventitious agents);

— verifying the theoretical assumptions underpinning the actions taken;

— formulating conclusions for other programmes and projects, promoting examples of good practice;

— building evaluation abilities;

- strengthening partnership and democratising social relations;

- developing and strengthening cooperation between the participants of a given intervention (networks of their mutual correlations, relations and interactions);

- activating stakeholders, engaging them in the implementation of activities, the discussion on assessing the programme/project and the directions of its development;

- empowering stakeholders, causing the process of shared decision-making on the programme/project to encompass those groups which usually remain, for instance, passive addressees of the actions or external implementers of the particular actions with little interest in the direct objectives of the interventions;

- creating a positive social climate around the project at hand, as well as around the activities of social welfare institutions - by providing information to the general public and disseminating evaluation results. ${ }^{2}$

Internal evaluation, in particular, may perform a number of additional functions, particularly relevant from the point of view of social work. As it is conducted by individuals involved in the reality under analysis, it influences the development of their self-awareness and makes them reflect on the value of their own actions, offers an opportunity for dialogue amongst employees on their own development and development of the institution/organisation, helps them improve their competences, gives them a sense of belonging to the team, motivates them to work better, acts as a tool which allows them to understand and simplify existing problems, as well as serves the purpose of building social trust towards support and assistance institutions and their officials.

In the Polish social welfare and integration system realities, evaluation is very often treated ritually, as an additional or even burdensome formal requirement, or - at most as an instrument of supervision and control, and not as a useful tool for increasing the efficacy and effectiveness of activities and supporting the management processes. In many

2 Prepared on the basis of Olejniczak, 2008; Ewaluacja..., 2004. 
cases, evaluation mainly performs latent (hidden) functions ${ }^{3}$, which are inconsistent with the purpose it should serve. For instance, it is intended to improve the image of the project-implementing institution, helps to avoid or dilute accountability for the actions and decisions taken, serves to legitimise the actions and decisions already taken, and may also help social workers to reduce stress or even burnout by compensating the lack of positive stimuli flowing from professional experience. This type of evaluation is very often prepared without setting detailed objectives, criteria and indicators, without being aware of its numerous functions that refer not only to clients but also to the clients' environment and the project implementer. It is often characterised by a selective choice of research methods and tools. As a consequence, the evaluation process actually encompasses only certain aspects of a given project and ignores those which could identify its weaknesses or failures (Faliszek, 2013; Faliszek et al., 2013).

A considerably more formidable barrier to popularising appropriate evaluation still seems to be the failure to understand the actual purpose it should serve. In public institutions (not only in social welfare), it continues to be understood and treated mainly as a technocratic tool of control, which generates reluctance and anxiety (Korporowicz, 2001). This concerns both rank-and-file (regular) employees and managerial staff at all levels. All this corroborates the thesis about the seemingness of evaluation activities in social welfare (Trawkowska, 2009), as the latent (hidden) functions often seem to dominate over the manifest (overt) ones, thus playing a stabilising role in this system by making it possible to positively assess the implementation of tasks without actual achievement of the objectives declared.

\section{Social worker as a researcher: an underrated innovation potential}

Due to the complexity and dynamics of the social reality in which public interventions are carried out, evaluation and evaluators are facing serious challenges. The necessity to take into account the wide context of planned and ongoing actions - assessing the possibilities of alternative solutions and their consequences, the variety of external and internal conditions affecting a given situation, the needs and behaviours of the stakeholders, the interests and values that guide them, their subjective feelings and opinions - all this determines the utility (usefulness) of any evaluation studies and makes it mandatory for their implementers to possess high levels of cognitive competence, i.e. relevant expertise along with the ability of its practical application. A particular role in researching the value of social programmes and projects is played by social workers, with all their skills and knowledge. Indeed, they are the ones increasingly expected to be not only the providers of various forms of support and assistance, but also the researchers of the reality in which they operate. Speaking of the researcher role assigned to social workers, what we most often mean is their duty to carry out diagnostic research which serves as the basis of and the starting point for all social interventions. Practice shows that it is not very common

3 Within the meaning given to that concept by Robert Merton, who indicated that latent (hidden) functions refer to objective effects of an element within the system, which were not planned or foreseen, regardless of whether they are positive or negative in nature (Merton, 1982). 
for social workers to have an opportunity to act as researchers. However, the situation is slowly changing and the researcher role is gradually consolidating its presence in the awareness of the social services representatives. This role also encompasses evaluation studies, which aim at measuring and assessing the quality of the effects produced by such interventions. This is because evaluation is a specific kind of re-diagnosis intended to demonstrate the change that has taken place as a result of the actions taken and how it has been achieved. Social workers combine two important resources of knowledge and skills - one is related to the methodology of conducting social research (which includes both diagnosis and evaluation studies), while the other is concerned with conducting methodological social work. This combination paves the way for a significantly broader and more in-depth perception of the reality in which a social intervention takes place and, thereby, may significantly increase the chances for an apt settlement in terms of one of the basic evaluation questions, namely to what extent the change observed is the result of an intentional social intervention and how likely it is that such a change would have occurred without this intervention. It is especially in the context of action research, used both in the diagnostic procedure and in evaluation under the development-oriented model, that social workers in their role as researchers gain the possibility for combining and confronting practice and theory, for better understanding of the complex relations and causal links in the reality under analysis, and - as a result, in cooperation with other stakeholders - for improving the ongoing projects, as well as finding new, more effective, efficient and satisfying solutions. If we agree that effective social intervention should be "tailor-made", i.e. constructed taking into account the specific features and situation of a particular client (individual, family, group or community), then thanks to such competences a social worker has a chance to look for and construct solutions, going beyond routine, proven, recognized actions, if they prove effective in this particular case.

Evaluation skills are undoubtedly one of the elements of occupational professionalisation amongst social workers and there are several determinants of this situation. In its attributive sense, professionalisation, i.e. "the process of socio-symbolic construction of a given profession or its status" (Frysztacki, 2008, p. 20), "the process through which a group of skills and activities is socially identified and defined as a profession, along with the determination of the required scope of knowledge encompassing the competences of a given profession" (Olechnicki \& Załęcki, 2004, p. 164), means that the representatives of a given profession become holders of its constituent features, such as high competence in terms of theoretical knowledge and practical skills, including methodology, a group of values making up the code of ethics, a publicly recognised authority, social control as part of the professional community and shared professional culture (for more on this subject, cf. Wódz \& Faliszek, 2017). Social work is an occupation which is undoubtedly transforming into a profession, but this process is still in statu nascendi, not fully coherent and highly inconsistent ${ }^{4}$, not without actions that could rather lead to its de-professionalisation

4 This is more widely discussed by M. Rymsza (2016), D. Trawkowska (2009a), and E. Kantowicz (2011). 
(Wódz, 2013; Wódz \& Faliszek, 2017). This basically concerns all of the above-mentioned attributes of a profession, including the one which determines its contents and boundaries, i.e. knowledge and skills 5 . Professionalisation should increase the quality of social services, including the methodical social work, thereby enhancing the efficacy of pursuing the main objective of social welfare, which is to bring back the clients' ability to independently cope with difficult situations. However, professionalisation should also result in greater empowerment of social workers themselves and their integration around the main values and objectives of the profession, common for all welfare specialities (Rymsza, 2016). If this process is to continue, it seems that evaluation may play a significant role in this respect. However, if matters take the opposite course, towards deprofessionalisation and/ or deregulation of the profession, it is the evaluation competences that may prove to be the cement helping to maintain professional integration and identity of social workers.

\section{Final remarks}

The role of evaluation in further professionalisation of social work as a profession is related, to the greatest extent, to its development-based and participatory models. If evaluation is treated as support in the process of learning and better understanding, thanks to all of the -advantages of this approach mentioned above, it will constitute an important factor in strengthening the occupation as a profession.

Firstly, it may lead to the development of professional knowledge, competence and skills of social workers, including in the very important aspect of putting these elements into practice. Since, as noted by Krzysztof Frysztacki in his deliberations on the professionalisation of social work, the initial feature of knowledge in social work is "... the need and ability to make decisions in precarious situations, as well as take into account the conditions affecting those situations" (Frysztacki, 2019, p. 221), increasing importance is being attached to the possibility of verifying - in the course of the evaluation procedure - such elements of knowledge that translate into the best possible results for the beneficiaries of the support measures in each individual case (intervention). Given how interdisciplinary the sources of this knowledge are, evaluation may certainly be helpful also in improving the coherence of this knowledge as specifically inherent in social work through its practical (useful) implications.

Secondly, the possibility of influencing public opinion by showing actions focused on increasing the efficiency and effectiveness of social work in cooperation with beneficiaries and other stakeholders of social interventions may translate into the construction of public authority and prestige of social work as a trustworthy profession, which, as we know, is highly problematic in Poland today.

Thirdly, the development of social relations and the network of interconnections, resulting from the application of the participatory methods of evaluation studies

5 This is more widely discussed by K. Wódz in the context of standardisation of social welfare work (2013, p. 63). 
(e.g. action research) may become an important factor for reintegration of the professional environment, which, following a period of failures (failed integration under the Polish Association of Social Workers [Polskie Towarzystwo Pracowników Socjalnych]), is trying to consolidate again (within the framework of the Polish Federation of Social Workers and Social Service Employees Unions [Polska Federacja Związowa Pracowników Socjalnych $i$ Pomocy Spotecznej]) and, additionally, must face the challenges related to the emergence of new welfare specialisations (Rymsza, 2016).

Fourthly, even though the rules of professional ethics for social workers in Poland are codified ${ }^{6}$, studies indicate ${ }^{7}$ that the code of ethics as an essential deontological document is poorly rooted in their awareness and does not constitute a reference to the common, everyday professional practice. The experience related to participation in the evaluation studies of the projects implemented may lead to greater realisation of the sense and meaning of these rules, as well as of the need to refer to them in social welfare efforts.

Fifthly, the development of self-reflection and self-awareness driven by the evaluation practice may also be a crucial factor conducive to the development and dissemination of professional culture in the environment of social workers.

These very promising possibilities related to the participation of social workers in the evaluation process based on the development-oriented model (dialogic, participatory) create a very optimistic vision, yet unfortunately very unrealistic, if not utopian, for a number of reasons. Some of those reasons are indicated above, but perhaps the most significant ones are related to the broadly conceived situation in today's support and assistance system in Poland. Raising the issue of social workers being underpaid and chronically overloaded with administrative and bureaucratic duties sounds like a platitude today, because it repeatedly resounds in every single discussion on social welfare. However, a real threat is also the fact that the changes in legal regulations implemented for years will lead to gradual de-professionalisation of social work. Starting from the Act on family benefits $^{8}$, through the Act on family assistance ${ }^{9}$, to the latest regulations concerning the

${ }^{6}$ Even in two variants, slightly different from each other. One is the Code of Ethics of the Polish Association of Social Workers [Kodeks Etyczny Polskiego Towarzystwa Pracowników Socjalnych] while the other - the Code of Ethics of Social Workers and Social Service Employees [Kodeks Etyczny Pracowników Socjalnych i Pracowników Pomocy Spotecznej] of the Polish Federation of Social Workers and Social Service Employees Unions.

7 For instance, the study conducted under the project entitled "Creating and developing the standards for social welfare and integration services" (Polish title: Tworzenie i rozwijanie standardów ustug pomocy $i$ integracji spotecznej), implemented through a partnership of eleven non-governmental organisations (NGOs) operating in social welfare and policy, whose leader was the Human Resources Development Centre (Centrum Rozwoju Zasobów Ludzkich).

8 Act of 28 November 2003 on family benefits (Dz.U. [Journal of Laws] of 2003, No. 228, Item 2255).

9 Act of 9 June 2011 on supporting the family and the foster care system (Dz.U. [Journal of Laws] of 2011, No. 149, Item. 887). 
centres of social services ${ }^{10}$ (in the meanwhile, there were also projects which, perhaps we should say "luckily", were not implemented, for instance the 2007 bill on the rules of pursuing social policy ${ }^{11}$ or the 2014 draft amendment to the Act on social welfare ${ }^{12}$, which after all seems to be a source of certain inspirations for the latest regulations), social work is being gradually pushed out of yet more areas of its activity. Referring to the otherwise quite legitimate proposals of social workers concerning the separation of social work from the administration of pecuniary benefits, and to the need to de-stigmatise social welfare as an institution involved primarily in the distribution of those benefits, as well as to the necessity of increasing access to social services and improving their quality, undermines the importance of social work as a profession characterised by specific, highly professional attributes presented above. Moreover, it opens up an area of conflict between social workers equipped with complex and advance methodology and new professions defined as 'separate', while de facto functioning earlier as specialisations within the area of social work ${ }^{13}$.

The objectives that guided all of the above-mentioned changes in legal regulations ${ }^{14}$ had already been pursued by some social welfare centres prior to their implementation thanks to specialised social workers. Therefore, these objectives were, and still are, achievable without the need to create additional entities in the form of new institutions or separate welfare professions. All that needs to be done is to direct all efforts towards strengthening methodical social work and creating better conditions for the professional development of social workers by supporting their potential to specialise in working with different type of clients, various social problems and diverse methods of social work. In large welfare centres, we can already find many social workers who are top professionals and specialists in solving the most difficult social problems in miscellaneous areas ${ }^{15}$. The current system of education for social work makes it possible for a considerably greater number of such specialists to work in social welfare. However, it is important that they also find employment in small social welfare centres, where professional social work is "a particularly rare commodity". Meanwhile, however, in the situation when the process of professionalisation of social work is facing these difficult challenges, it is the pressure on well-conducted evaluation of social projects and interventions that acts as an asset for strengthening this process. It is only the evaluation studies that are able to best demonstrate the actual conditions for

10 Act of 19 July 2019 on providing social services by the centre of social services (Dz.U. [Journal of Laws] of 2019, Item. 1818).

11 http://orka.sejm.gov.pl/Druki5ka.nsf/0/677B975EDE36FE94C12572AC0038E58C/\$file/1548. pdf; accessed on: 31 $1^{\text {th }}$ October 2019.

12 https://efs.mrpips.gov.pl/_data/assets/pdf_file/0007/2500/21_projekkt_zalozen_do_zmiany_ ustawy_o_pomocy_spolecznej.pdf; accessed on: 31 ${ }^{\text {th }}$ October 2019.

13 The most spectacular example is the job of a family assistant (Rymsza, 2016).

14 Incidentally, the said regulations have not brought about any spectacular increase in the efficacy and effectiveness of pursuing these objectives.

15 These include, amongst others, employees with second-degree professional specialisation confirmed by a certificate from the Central Examination Board attached to the minister in charge of social policy. 
efficacy and effectiveness in welfare activities, with a number of these conditions being related to methodical social work in which social workers make use of advanced tools and methods as elements of their own base of professional skills and knowledge. The presence and indispensability of evaluation in social work is an undisputed fact today, especially within the groups of social workers themselves. Appreciation of this fact and commitment to improve the research competences necessary for conducting evaluation represent an important factor that reinforces the profession in the context of interaction with other jobs, including other welfare specialisations, as well as in the context of its development as an academic discipline (Frysztacki, 2019).

\section{References}

Ewaluacja w administracji publicznej. Funkcje, standardy $i$ warunki stosowania (2004). Comp. by K. Ekiert. Rządowe Centrum Studiów Strategicznych.

Faliszek, K. (2013). W poszukiwaniu ewaluacji. Przegląd projektów systemowych ośrodków pomocy społecznej województwa śląskiego. In K. Faliszek (ed.), Wprowadzenie do badań ewaluacyjnych. Aspekty teoretyczne i praktyczne na podstawie doświadczeń badawczych. Wydawnictwo Edukacyjne AKAPIT.

Faliszek, K., \& Leśniak-Berek, E. (2010). Praca socjalna w projektach systemowych ośrodków pomocy społecznej w województwie śląskim. In A. Kanios, \& M. Czechowska-Bieluga (eds.), Praca socjalna. Ksztatcenie — działanie — konteksty. Oficyna Wydawnicza impuls.

Faliszek, K., Libor, G., Muster, R., Nowalska-Kapuścik, D., \& Szpoczek-Sało, M. (2013). Fundusze unijne zmieniają Polskę? Analiza ewaluacji projektów unijnych na przykładzie województwa ślaskiego. Wydawnictwo Uniwersytetu Śląskiego.

Frysztacki, K. (2008). Siła i słabość procesów profesjonalizacji pracy socjalnej. In B. Matyjas, \& M. Porąbaniec (eds.), W drodze ku profesjonalizacji zawodu pracownika socjalnego. Wydawnictwo Akademii Świętokrzyskiej.

Frysztacki, K. (2019). Wokót pracy socjalnej. Od koncepcji i teorii do kontekstów empirycznoedukacyjnych. Wydawnictwo Uniwersytetu Jagiellońskiego.

Górniak, J. (2005). Ewaluacja jako czynnik doskonalenia zarządzania strategicznego w administracji publicznej: projekt SAPER. In Ewaluacja programów o charakterze spoteczno-gospodarczym finansowanych z funduszy strukturalnych. Ministerstwo Gospodarki i Pracy, Państwowa Agencja Rozwoju Przedsiębiorczości.

Kantowicz, E. (2011). Kultura profesjonalizacji pracowników socjalnych i jej kształtowanie w procesie edukacji. In K. Piątek, \& K. Szymańska-Zybertowicz (eds.), Profesjonalna praca socjalna. Nowy paradygmat czy niedokończone zadanie? Wydawnictwo Edukacyjne AKAPIT.

Korporowicz, L. (2001). Ewaluacja i społeczeństwo. In E. Hałas (ed.), Rozumienie zmian społecznych. Towarzystwo Naukowe Katolickiego Uniwersytetu Lubelskiego.

Korporowicz, L. (2005). Analiza dotychczasowych doświadczeń z zakresu ewaluacji funduszy strukturalnych w Polsce i opracowanie metodologii przeprowadzania oceny szacunkowej wstęnego projektu NPR 2007-2013. Ekspertyza dla Ministerstwa Gospodarki i Pracy. 
Merton, R. (1982). Teoria socjologiczna i struktura społeczna. Państwowe Wydawnictwo Naukowe.

Nevo, D. (1997). Konceptualizacja ewaluacji edukacyjnej. In L. Korporowicz (ed.), Ewaluacja w edukacji. Wydawnictwo Oficyna Naukowa.

Nowalska-Kapuścik, D. (2013). Historia ewaluacji w Polsce i na świecie. In K. Faliszek (ed.), Wprowadzenie do badań ewaluacyjnych. Aspekty teoretyczne i praktyczne na podstawie doświadczeń badawczych. Wydawnictwo Edukacyjne AKAPIT.

Olechnicki, K., \& Załęcki, P. (2004). Stownik socjologiczny. Graffiti BC.

Olejniczak, K. (2008). Mechanizmy wykorzystania ewaluacji. Studium ewaluacji średniookresowych INTERREG III. Wydawnictwo Naukowe SCHOLAR.

Ornacka, K. (2003). Ewaluacja. Między naukami społecznymi a praca socjalna. Wydawnictwo Uniwersytetu Jagiellońskiego.

Rymsza, M. (2016). Jaka profesjonalizacja pracy socjalnej w Polsce i jaki rozwój służb społecznych? Problemy Polityki Społecznej. Studia i Dyskusje, 35(4), 25-42.

Szyszka, M. (2013). Ksztattowanie wizerunku instytucji pomocy spotecznej w mediach. Centrum Rozwoju Zasobów Ludzkich.

Trawkowska, D. (2009). Działania pozorne w pomocy społecznej — przejawy — mechanizmy — skutki. Przeglad Socjologiczny, 58(1), 129-147.

Trawkowska, D. (2009a). Profesjonalizm w parcy socjalnej - perspektywa teoretyczna i empiryczna polskich doświadczeń. In W. Szymczak (ed.), Wspótczesne wyzwania $i$ metody pracy socjalnej. Towarzystwo Naukowe Katolickiego Uniwersytetu Lubelskiego.

Ustawa z dnia 19 lipca 2019 roku o realizowaniu usług społecznych przez centrum usług społecznych, Dz. U. 2019, poz. 1818.

Ustawa z dnia 28 listopada 2003 roku o świadczeniach rodzinnych, Dz. U. 2003 nr 228, poz. 2255.

Ustawa z dnia 9 czerwca 2011 roku o wspieraniu rodziny i pieczy zastępczej, Dz. U. 2011, nr 149, poz. 887.

Wódz, K. (2013). Instytucjonalne bariery rozwoju środowiskowej metody pracy socjalnej / organizowania spoteczności lokalnej w Polsce. Ekspertyza przygotowana dla Instytutu Spraw Publicznych w ramach projektu systemowego 1.18: „Tworzenie i rozwijanie standardów usług pomocy i integracji społecznej”.

Wódz, K., \& Faliszek, K. (2017). State regulation of the social work profession: an example from Poland. In B. Blom, L. Evertsson, \& M. Perlinski (eds.), Social and Caring Professions in European Welfare States. Policy Press. 